\title{
The Hybrid Block as Urban Form
}

\author{
Javier Pérez Igualada \\ Escuela Técnica Superior de Arquitectura, Universitat Politécnica de Valènđa. Valencia, Spain \\ E-mail: jperezi@urb.pv.es
}

\begin{abstract}
In this paper we analyze the hybrid block as an urban form of synthesis, in which the open order of modern urbanism is superimposed on the closed order of traditional urbanism. In this model, proposed for the first time by Hilberseimer in his 1924 Hochhausstadt (Highrise City), housing and work are not separated but overlapping on mixed-use buildings, where the dwellings are located in slabs or towers shaped as isolated volumes, whose design responds to its own internal logic, based on functional criteria (rational distribution of rooms, orientation, ventilation, sunshine, views...). Those volumes emerge from a compact built-up podium for commercial or office uses, aligned with the perimeter streets and responding to the external logic of the urban fabric. This configures an urban form in which both hybridization of architectural forms and hybridization of uses are obtained, recovering the multifunctional character of the traditional urban block, which had disappeared in functionalist urbanism. The paper examines the reasons that can explain the exclusion of this urban form from the repertoire of elements of modern urbanism, and analyzes the validity of the hybrid block, as an strategy to recompose or reinterpret the urban block, assuming high density and collective housing as a basic typology for the construction of the city.
\end{abstract}

Keywords: Hybrid Block, Urban Form, Mixed Use Buildings, Open Planning

\section{Life and death of mixed-use buildings in modernist housing.}

In the traditional city, housing and work shared the same building: the productive activities, such as the workshop of the craftsman or the spaces for the commerce, were on the ground floor and the dwellings were placed above. The only existing residential type was the singlefamily house, linked to its plot, to the land.

This situation changes in a radical way in the industrial city, where collective housing, with rental apartments in multi-storey buildings, consolidates as predominant typology and basic element of an urban fabric composed of city blocks. This type integrates in the beginning a non-residential ground floor, intended for offices or shops, but the productive activity (factories) progressively moves out of the city due to the need for more space and to improve its link with the transport networks.

The facades of the buildings in the urban city block are aligned with the street, configuring a closed continuous envelope. The interior of the block may have more or less free space, depending on the historical period, the local building tradition and the degree of densification reached in each city.

In any case, the buildings in the closed urban city block are mixed use: the ground floor (and sometimes the mezzanine) has a nonresidential destination (offices, shops) and the upper floors are allocated to dwellings, socially stratified until the use of the elevator became widespread. The privacy gradient increases as we ascend: shops open to the public and to the street at ground floor, mezzanine offices and dwellings above.

This type of mixed use building was condemned without palliatives and drastically 
expelled from the city of the modernist architecture. This expulsion can be explained by a series of confluent factors, some of which are related to urban concepts while another ones are of aesthetic order.

The first of these factors is the emphasis placed on housing by the modernist movement, to the detriment of other urban elements. The functionalism focused adequately on solving the problems that affected the conditions of habitability in the industrial city (overcrowding, insalubrity and lack of free spaces). But the emphasis placed on the residential reached to such an extent that residence was considered as the basic element for the construction of the modernist city, neglecting other constituent elements of the urban reality traditionally linked to housing, mainly the shops and working places located in the ground floors of residential buildings.

This attitude can be explained in part by the fact that the object of modernist urban design in its founding period was mainly the residential suburb, the siedlung or colony of worker's housing, where a commercial activity comparable to that of a traditional urban fabric was not foreseeable. The model of garden-city that is at the origin of the German siedlungen of the 20 s did not contemplate mixed use buildings, since its basic residential type was the single family house with a private garden.

The second factor, complementary to the previous, is the generalized application of the parallel concepts of zoning and functional specialization in modernist urbanism. This means, on the one hand, that the city is subdivided into zones for different uses, and, on the other, that buildings are designed from inside to outside, according to the formfollows-function principle.

The mixing of uses is considered as an anathema in the CIAM theories about urbanism, such as the 1933 Athens Charter. In the city of modern architecture, therefore, housing and commerce cannot coexist in the same building: shops, restaurants and other establishments disappear from their traditional location under the dwellings, and these tend to occupy also the ground floor, configuring uni-functional buildings, exclusive for residential uses.

The traditional model of shops along commercial streets is replaced by another where shopping is concentrated in buildings designed for that exclusive use (markets or commercial centers). As a consequence, the street is deprived of much of its activity, to the point that it can hardly survive as a living urban place if its only role is as a space to park cars and give access to housing.

A third factor that explains the exclusion of mixed use buildings in modernist urbanism is related with the proposed disposition of the buildings with respect to the streets, not aligned but independent of them, with access through pedestrian paths inserted in green spaces. This separation between buildings and streets turns the streets into mere roads, and makes unfeasible, even if it is postulated, to place commercial spaces on the ground floors of these buildings, since they would have a difficult supply and, moreover, no one would pass in front of them except the residents themselves.

This organization of the ground plan makes the mixed building impossible in modernist housing complexes. If the residential buildings are separated from the street and immersed in the green, the dwellings' habitability conditions may be improved, but at the same time shops are isolated from the flow of people necessary for any commercial activity.

A fourth factor, of a compositional or aesthetic nature, reinforces this: for modern architecture, the heavy basal body of classical buildings is unbearable, aberrant: there are no structural walls anymore, and the pillars must be seen, making ostentation of the new structural techniques made possible by the use of rolled steel and reinforced concrete. On the ground floor there is occasion to express the triumph of the new, and the building on pilotis proposed by Le Corbusier in his famous cinq points perfectly expresses the machinist aesthetic, the lightness and the break with the classic composition. Ville Savoye, at the scale of the private house, and the Unité D'Habitation, at the scale of collective housing, propose just the same relationship with the land: not to touch the natural landscape, but to settle the buildings on it instead, leaving it almost intact. There is no possible shop under a building so conceived.

The only urban proposal of its time in 


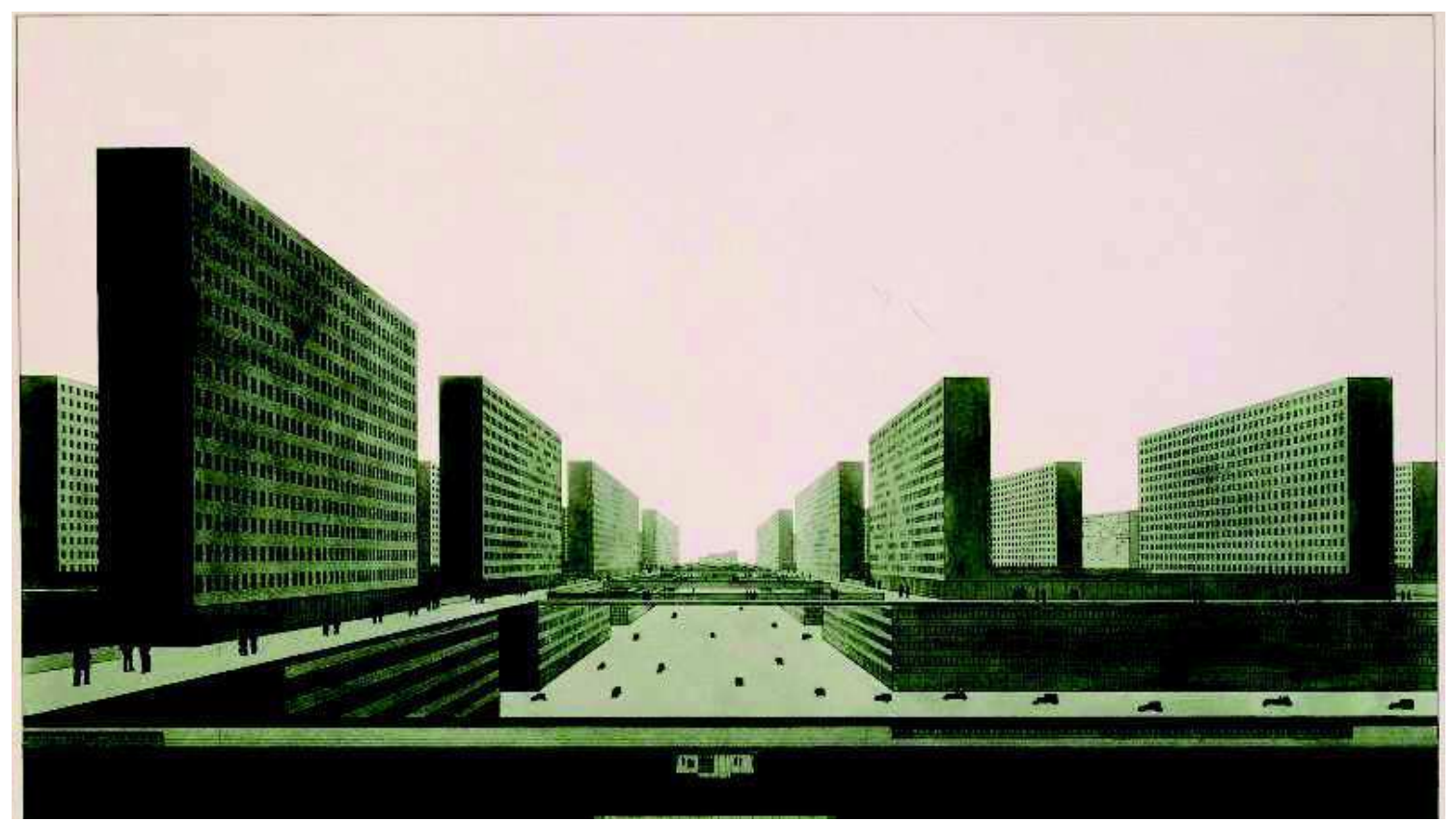

Figure 1.

Ludwig Karl Hilberseimer. Highrise City (Hochhausstadt): Perspective View: North-South Street, 1924. Ink and watercolor on paper, Approx. 97.3 x $140 \mathrm{~cm}$. Gift of George E. Danforth, 1983.992. Architecture and Design collection. Chicago Art Institute.

Europe in which housing and working are not separated but overlapping on mixed-use buildings is the Hochhausstadt o High-rise City, designed by Ludwig Hilberseimer in 1924, which, as opposed to the successful proposals of Le Corbusier and the Charter of Athens, was ignored by its contemporaries and discarded by its own author. Hilberseimer's Hochhausstadt, however, marks the birth of the hybrid block idea in the modernist urbanism, so we will analyze it in detail in the next section.

\section{The hybrid block in Hilberseimer's Hochhausstadt: a forgotten model in modernist urbanism.}

Ludwig Hilberseimer designed in 1924 an ideal city, the Hochhausstadt (High-rise City or Vertical City), which differs from all other urban proposals of that time in Europe because it is the only model in which housing and working are not separated but overlapping on mixed-use buildings.

The proposal for the Hochhausstadt, published in 1927 in the book Grosstadt Architektur, consists of three drawings only: a schematic plan and two perspective views of a south-north street and an east-west street. This images of the High-rise City have been used frequently to show the dehumanized character of the modern city and the stark horror of the metropolis, expressed in the anonymous and absolutely uniform architecture.

But the Hochhausstadt, if we can see beyond the raw images, is a precise urban model that does not imply a rupture with the urban tradition, but rather a reinterpretation of that tradition from new parameters.

Hiberseimer proposes in his Vertical City a rational organization (inspired by the highrise building of American cities but opposed to the chaos of those) and isotropic (opposed to the hierarchical order of Le Corbusier's Ville Contemporaine), which takes the form of a homogeneous orthogonal grid. This grid is formed by blocks of 100x600 m, with its long side in a north-south direction, and streets of 60 $\mathrm{m}$ wide. The length of the block is given by the distance between metro stops.

Assuming high-density and collective housing as project premises to build the Grosstadt, Hilberseimer's Vertical City consists of two overlapping cities: underneath 
the commercial city and round circulation; above, the residential city and the pedestrian circulation. Urban and interurban transport services run underground.

The endless grid of rectangular blocks of the Hochhausstadt is composed by the repetition of an only building type, composed of isolated slabs for dwellings on a non-residential base structure built as a conventional city block.

The lower part of the block, five storeys high, is intended for commercial and working uses, which occupy the perimeter of the block in a strip with a depth of $15 \mathrm{~m}$ and transverse built strips that separate seven interior courtyards per block.

The upper part of the block, intended for residence, is composed by two linear slabs, 15 storeys high, arranged longitudinally in a north-south direction, $10 \mathrm{~m}$ depth and with a setback of $8 \mathrm{~m}$ with respect to the alignment of the commercial base. The space of this setback, extended on the street by a cantilever of $2 \mathrm{~m}$, is used for pedestrian circulation. The linear slabs are thus separated from each other at regular intervals of $70 \mathrm{~m}$, both on the sides of the street and inside the block, being the street width equal to the height of buildings.

In the Hochhausstadt, dwellings are located in slabs shaped as isolated volumes, whose design responds to its own internal logic, based on functional criteria (rational distribution of rooms, orientation, ventilation, sunshine, views...). Those volumes emerge from a compact built-up podium for commercial or office uses, aligned with the perimeter streets and responding to the external logic of the urban fabric.

This configures an urban form in which both hybridization of architectural forms and hybridization of uses are obtained, recovering the multifunctional character of the traditional urban block, which had disappeared in the functionalist urbanism of the 20s.

The hybrid block as an urban form associated with the contemporary city is thus configured in the urban proposals of Hilberseimer as an urban form of synthesis, in which the open order of modern urbanism is superimposed on the closed order of traditional urbanism.

The Hochhausstadt model was left dead as an urban system for residential complexes, because it did not fit into the strict functionalist zoning doctrine, which did not allow the mixing of housing and commerce in a single building.

However, the hybrid block will have more fortune as a model for central urban areas, characterized by a high demand of surface for commercial and office uses. As early as 1925 , Cornelis van Eesteren used this model in his project for Unter den Linden in Berlin, as well as in his 1926 studies for the reorganization of the center of Paris. Hilberseimer himself proposed in 1930 a modified version of his Vertical City for the center of Berlin, in which the linear slabs are eight-storey office buildings, located on a two-storey base that occupies the whole block. But although the organization of the volumes is similar, at a reduced scale, than the one presented in the Vertical City, this does not occur with the uses: instead of the mixed use block of the Hochhaustadt, in the project for Berlin the block is destined only to shops and offices, and housing is excluded. The architectural hybridization, with the linear slabs superimposed on a compact basement, is not joined by a functional hybridization, so horizontal zoning persists, losing the main virtue of the Vertical City: the overlapping of housing and working.

The recovery of the hybrid block in the 60s: platforms, megastructures and multifunctional urban centers.

From the beginning of the sixties, the strict orthodoxy of modernist functionalism is progressively abandoned in favor of urban models based in a mixture of uses, where complexity and multi functionality are perceived as a necessary factor to recover the urban character and the traditional street life in housing complexes. This is the position advocated by Jane Jacobs in her very influential book The Death and Life of Great American Cities (1961), which marks a turning point in contemporary urbanism.

The horizontal separation of activities induced by zoning regulations, which segregate the four functions identified in the Athens Charter (dwelling, working, recreation and circulation), had already been questioned in 1959 in the CIAM of Otterlo by the new generation of architects grouped in the Team 


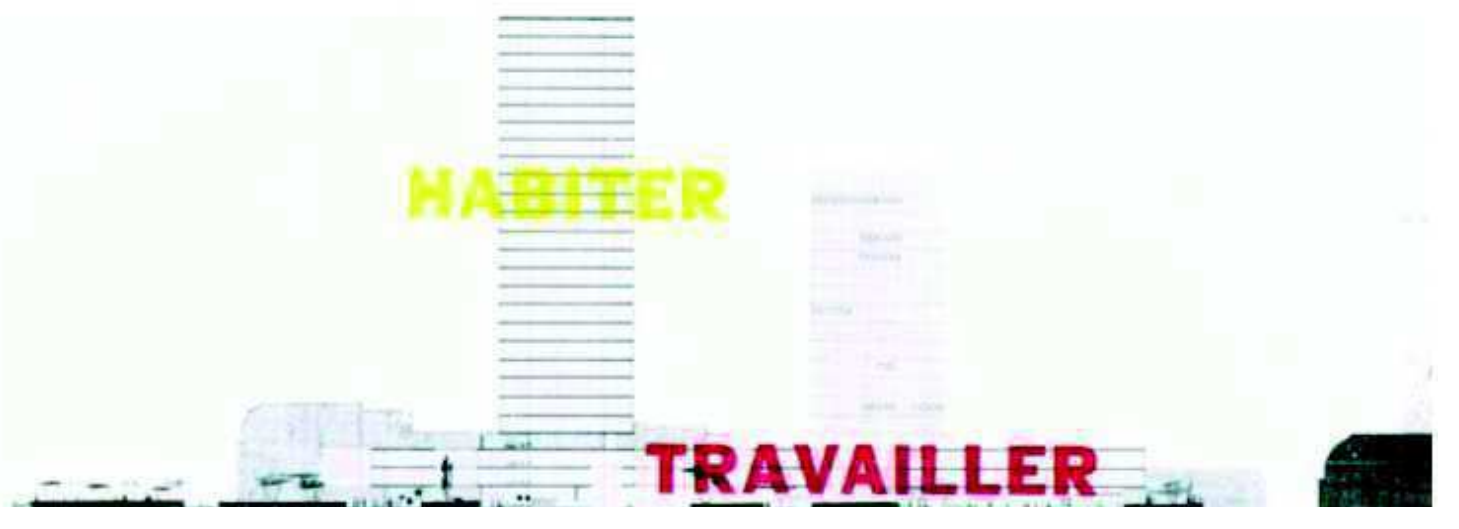

Figure 2.

Michel Holley. Proposal for a vertical zoning: living-working-circulation.From: Holley, Michel (2012). Urbanisme vertical \& autres souvenirs (Somogy éditions d'art, París).

10, such as Aldo Van Eyck, Jaap Bakema or Alison and Peter Smithson. That same year, the project for Front de Seine contest in Paris by Raymond López, Henry Pottier and Michel Proux, with Michel Holley, laid the foundations of what in France will be known as urbanisme de dalle (urbanism of platforms), a model where the horizontal zoning of the CIAM is abandoned, and functionalism is reinterpreted by proposing a vertical zoning, in which functions overlap vertically: the roadways in the subsoil, the shops and work areas on the surface and housing high above, emerging from the new artificial and elevated floor plan of the dalle. This model represents a recovery of the hybrid block as an urban element, and derives directly from the one proposed by Hilberseimer in his Hochhausstadt, with two main differences: the use of subsoil for traffic and the building typology of the volumes that emerge from the base structure, which are now towers instead of linear slabs.

Other architectural and urban proposals that seek to recover multi-functionality in the $60 \mathrm{~s}$, such as the Pampus Plan for Amsterdam by Bakema and Van den Broek or Cumbernauld town center, are based on the concept of megastructure, a term coined by Fumihiko Maki in 1964 to designate one of the possible ways of creating collective forms (the other two methods are the compositional form and the grouped form). The megastructure, according to Maki, is a mega-form or structural support, in which are housed smaller units that can be added or removed. This concept contradicts the idea of block, understood as a discrete unit that by repetition configures the grid, the urban fabric. The concept of megastructure, therefore, allows to create hybrid buildings, but not hybrid blocks.

In the United States, Victor Gruen, who paradoxically had been the creator and main designer of the 1950s suburban shopping center, follows Jacobs' questioning of the functionalist zoning in his book Centers for the Urban Environment (1973), where advocates a new commercial model based on the vertical overlap of uses: the multifunctional urban center.

The aim of a multifunctional center is to combine as many urban functions as possible in a compact structure that uses the land intensively to obtain the maximum gross surface area for human activities, occupying as little terrain as possible. The concentration and superposition of functions allows shortening the distance between them, and minimizes the cost of forced mobility. Gruen shows as examples of this new model his projects for Midtown Plaza (Rochester, 1962) and Tête Defense (Paris, 1970), and the Barbican development of Chamberlain, Powell and Bon (London, 1969), among others.

The organizational principle for the volumes in the multifunctional urban center follows what Gruen calls the "platform principle". According to this principle, all functions that can best be performed under controlled airconditioning and lighting conditions, together with all services, public transport and parking 

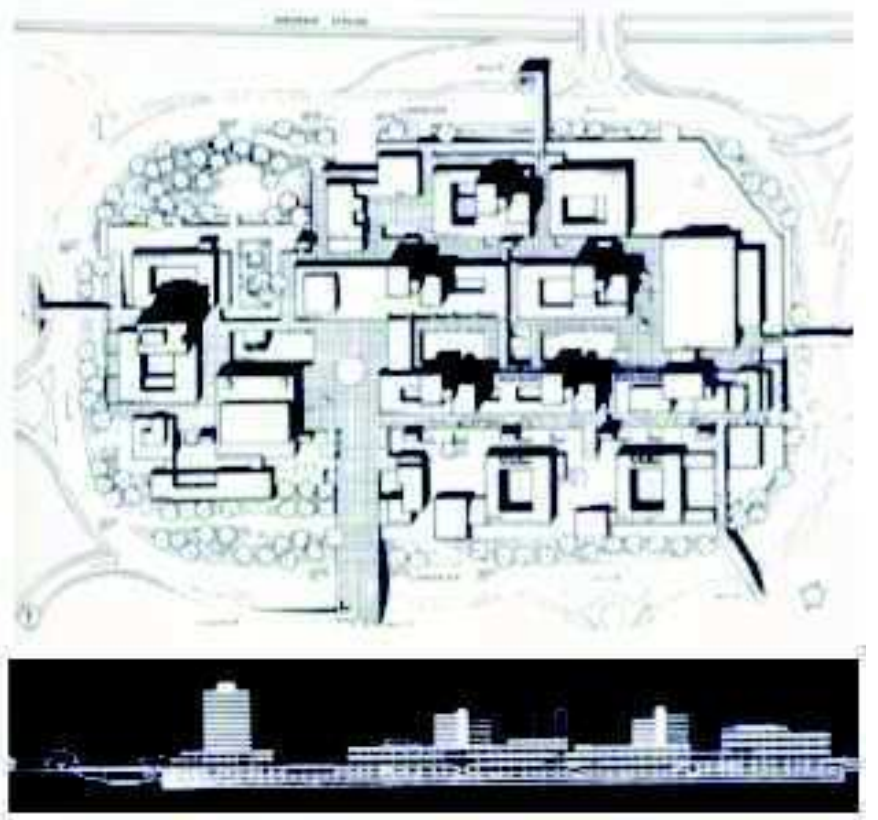

Figure 3.

Nordwest Stadt Centre. Frankfurt. Plan and general section. $\mathbf{H}$. Kampffmeyer, Frankfurt Planning Office. From: Gruen, Victor (1973). Centers for the Urban Environement. Survival of the Cities (Van Nostrand Reinhold, New York).

facilities, can be located in what Gruen calls "base structure", that can start with two or three basement levels and finish with two or more levels above grade. This base structure constitutes a compact and homogeneous volume, which is destined for the most part to lucrative uses, along with the pedestrian spaces like squares and galleries that serve them. As in the French dalle, the upper limit of the base structure forms a "platform" which is not necessarily a flat surface, but can be organized as a series of terraces at different levels, linked together. This platform doubles the surface of the plot, creating a new floor plan, pedestrian and landscaped, from which the volumes corresponding to urban functions that need natural ventilation and illumination, for physical or psychological reasons, emerge: hotels, offices, civic or administrative buildings, apartments, which may have different heights and shapes on different floors.

In short, what Gruen proposes with its multifunctional urban center, as Holley does with his urbanisme de dalle, is what we can call a "hybrid superblock", a building complex of a much larger size than that of an urban block, and without plot subdivisions. This proposal, unlike the megastructural ones, has a possible fit in an existing urban fabric, since it implies only a concentration of plots to achieve a punctual extension of the size of the grid.

The arise of the neo-hybrids: mixed use and urban congestion in the contemporary city.

The hybrid block is the urban form selected by Rem Koolhaas in his 1972 render, The City of the Captive Globe, a fantastic city created to represent and celebrate Manhattan's "culture of congestion". The drawing, included in Koolhaas' book Delirious New York (1978), shows a grid of compact and uniform city blocks surmounted by heterogeneous buildings, such as the RCA Building from the Rockefeller Center, the towers of Le Corbusier's Plan Voisin, and all kind of heterogeneous structures (El Lissitzky's Lenin's Tribune, a fragment of the Berlin Wall, scenography from Doctor Caligari's Cabinet ...). Though Koolhaas' City of the Captive Globe and Hilbersimer's Vertical City seem very different in appearance, and are distant in time, they share a common guiding principle: the use of the hybrid block as basic element to build the urban fabric.

In The City of the Captive Globe Koolhaas proposes in a metaphoric way an urban model in which unity is provided by the city blocks below and diversity is accommodated in the structures emerging over them. That synthesis of discipline and freedom is the main feature of what Koolhaas calls "Manhattanism": the grid acts as a control mechanism in the horizontal land plane and the vertical direction is the domain of anarchy. The base structure can be thus considered as an extension of the urban discipline of the grid to the first storeys of the building, and above the volumes are free.

The first general interpretation of the hybrid type is due to Joseph Fenton, who agrees with Koolhaas as to the reasons that explain the dual character of the hybrid type: it was "a response 


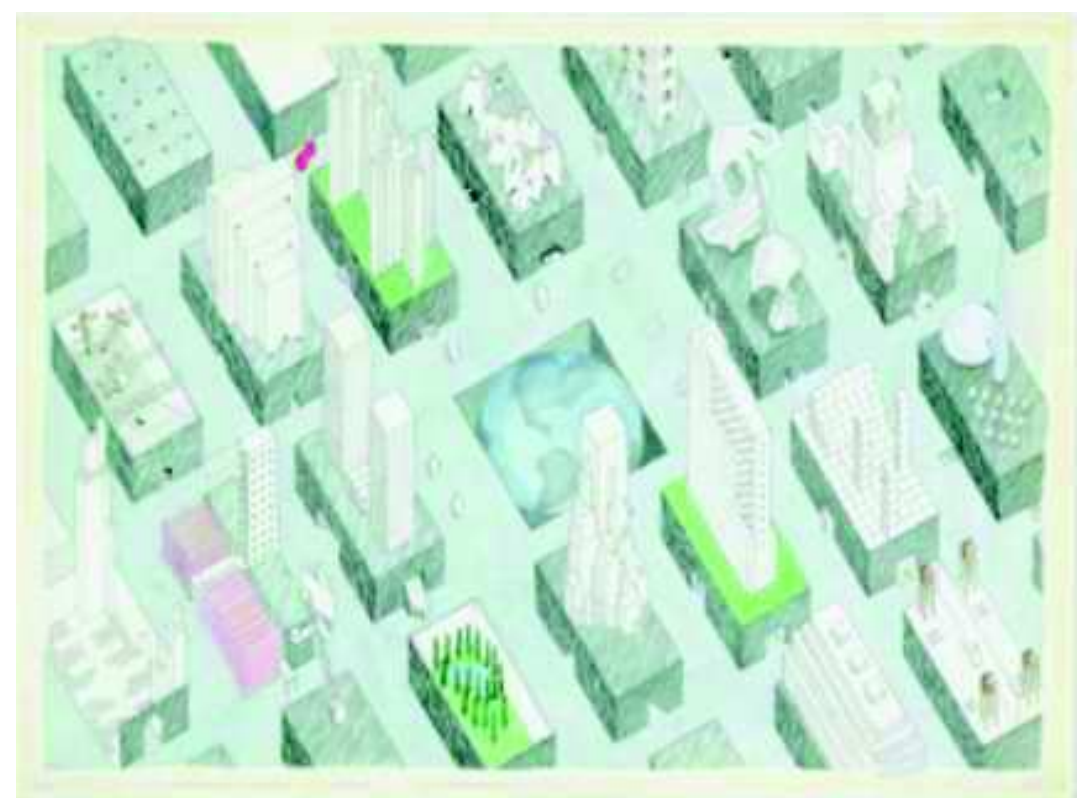

Figure 4.

Rem Koolhaas, Madelon Vriesendorp. The City of the Captive Globe Project, New York, New York, Axonometric, 1972. Gouache and graphite on paper, 31.8 $x 44.1 \mathrm{~cm}$. Gift of The Howard Gilman Foundation, Object number 1206.2000. Department of Architecture and Design. Museum of Modern Art, New York.

of hybrid buildings: Fabric, Graft and Monolith. In the Fabric and Monolith hybrids, programmatic elements are subsumed within a continuous building envelope. On the other hand, the Graft hybrid expresses its functional components, either volumetrically or in its elevation (Fenton, 1985). The hybrid block, as we have described it, could be somehow considered as a Graft hybrid building which occupies the land surface of a complete urban block.

In the debate on hybridization since the 1980s there are

to the metropolitan pressures of escalating land values and the constraint of the urban grid. With horizontal movement restricted, the city fabric moved skyward. The building form became taller, larger than ever before" (Fenton, 1985).

Fenton identified three different categories two trends, one urban but with a regressive approach, linked to what has been identified as "postmodernity", and another that we could call retro-futurist or neomodernist, which is inspired by the American culture of urban intensity of the early twentieth century, and implies to a certain extent a celebration of congestion.
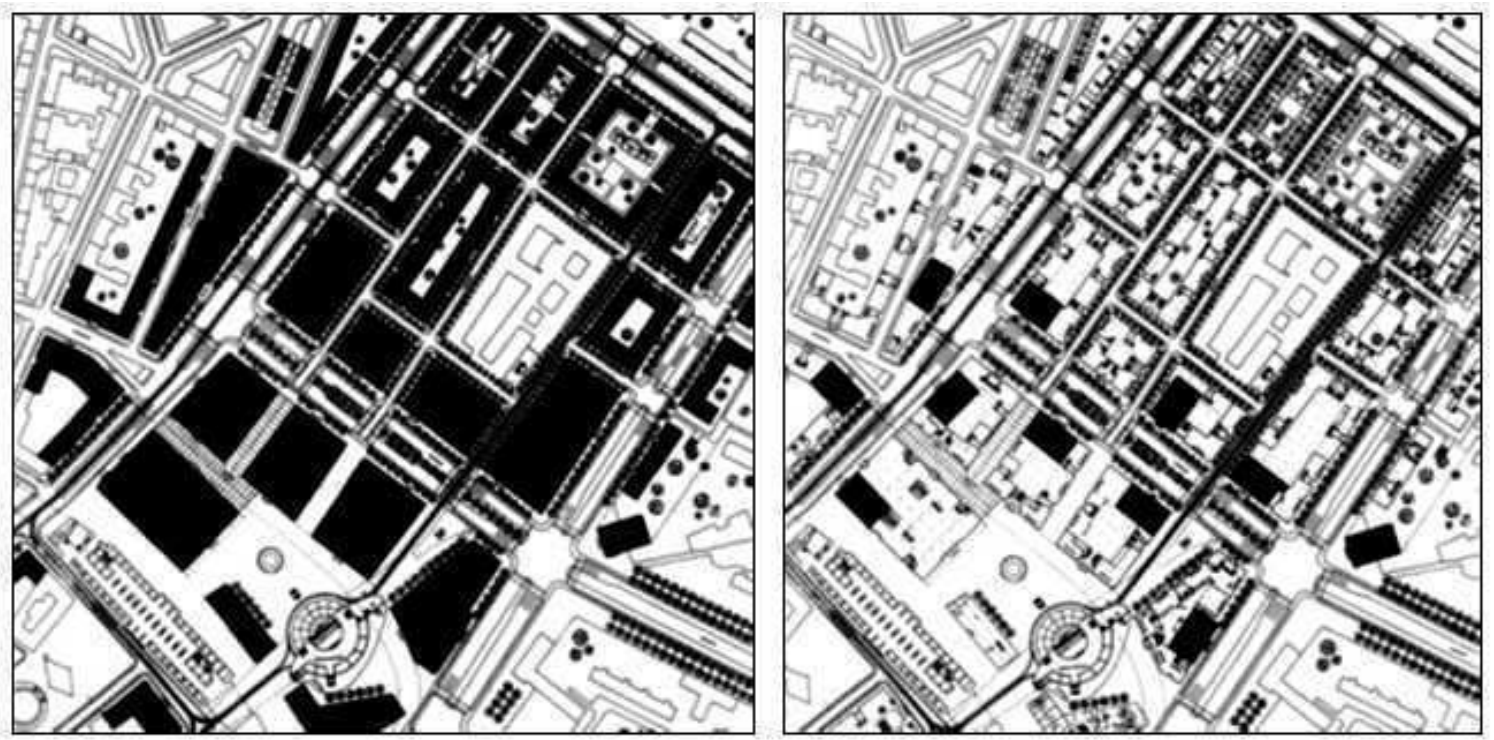

Figure 5.

Masterplan for Alexanderplatz, Berlín. Hans Kollhoff and Helga Timmermann, 1993. Ground floor and upper levels floor. From: Pérez Igualada, J. (2005): Manzanas, bloques y casas. Formas construidas y formas del suelo en la ciudad contemporánea (Universidad Politécnica de Valencia, Valencia). 


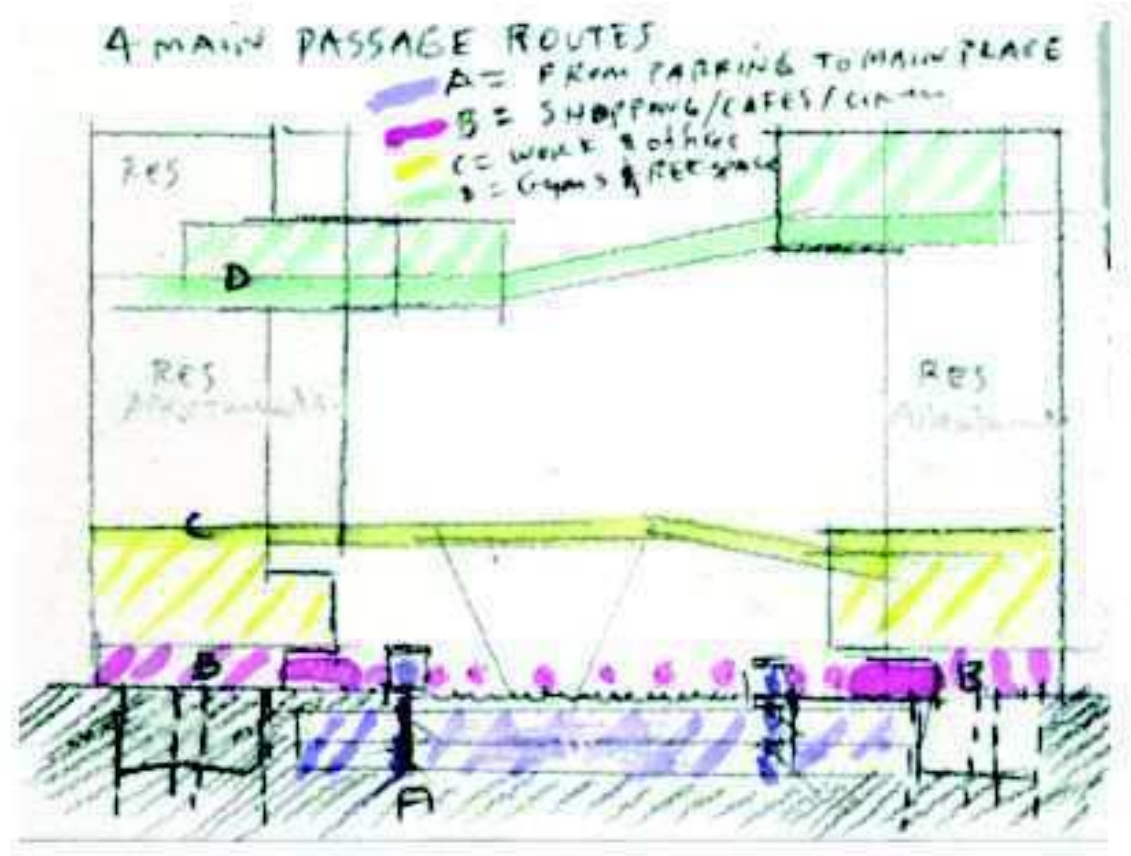

Figure 6.

Linked Hybrid block in Beijing (2003-09) by Steven Holl Architects. Sketch. From: http://www.stevenholl.com/projects/beijing-linked-hybrid

The hybrid block proposals that come from postmodernism look back at the traditional closed city block, which reappears in the designs of Rob and Leon Krier, Maurice Culot and the group of architects gathered around the magazine Archives d'Architecture Moderne.

From the 90's onwards, the discredit of postmodernism, together with a recovery of an urban design based in the open planning postulated by the modernist avant-gardes, will favor a renaissance of the mixed use building, within the framework of an attitude towards urbanism which we can call neo-modernist, an attitude which is no longer that of the urban planners of the modernist movement nor that of those who wanted to appear controversial with them in the 80s. Some relevant examples of it are the Linked Hybrid block (Beijing, 2003-09) by Steven Holl Architects and De Rotterdam building in Wilhelminapier (Rotterdam, 19972013) by Rem Koolhaas-OMA.

\section{Conclusion}

Parcellation is the procedure to subdivide the land in plots from the legal point of view. From the physical point of view, what interests us, however, is how this subdivision is expressed materially, how it is perceived visually and what it means in terms of urban form. In other words, what interests us when we approach the subject of the occupation of the land from the point of view of the urban form is how the floor plan is materially constructed.

In order to construct the floor plan in contemporary open-planning housing complexes, two procedures can be used. The first is to delimit clearly the properties with elements such as fences, hedges, enclosures, etc. The second procedure is associated with the use of the urban element we have called hybrid block. In short, this element consists on a base structure for non-residential uses, that works for urban purposes like the old compact 
city block, and isolated building volumes for residential uses emerging from that base, designed according to rational criteria of orientation, ventilation, sunshine and views.

The non-residential base is a podium that acts as a transition element between the housing volumes located on it and the surrounding streets. As a built-up link with ground level, the base is an element capable of responding to the demands of the urban context, the irregular geometries present in it and other conditions, such as property limits. This is possible for two reasons: on the one hand, by its autonomy with respect to the typology of the isolated volumes located on it, since the plan of the base does not need to match with the one of those volumes; on the other hand, by its non-residential destination, which makes it much more flexible than housing to absorb conditions derived from the context.

The hybrid block can configure an urban landscape made of closed blocks of small height on which volumes of all kinds emerge, creating a skyline varied and visually rich and stimulating, that changes according to the observer's position, with portions of sky always looming between slabs and towers, very different from the monotony induced by the uniform cornice in the traditional closed city blocks.

The boundaries between the public and the private are also clearly defined in the hybrid block: the private surfaces of land are built on the ground floor, either in full or in its perimeter, leaving private free spaces in form of internal gardens or courtyards. The free open space between slabs, which was a problematic space in modern urbanism when the footprint of the slabs reached the ground, has disappeared on the ground floor in the hybrid block, and exists only above the built-up base, as a platform linked to the slabs. This platform separated from the street is a private space, a new artificial floor which can be designed as a communal landscaped space (a green roof).

The footprint of the hybrid block, thus, is identical to the one of the traditional closed city block, so the streets can continue to play its structuring role as main elements of the public space. Examples of it are Hans Kollhof's proposal for Alexanderplatz in Berlin (1993), which is a reinterpretation of the Rockefeller Center model, and also the anonymous block composed by a pair of slabs over a commercial plinth, common on the periphery of many European cities.

The hybrid block, though recovering the modernist urban tradition, is not linked to the functionalist schematics, but incorporate instead the will to create an adequate urban form thorough a creative synthesis between project of buildings and project of spaces.

\section{References}

Fenton, Joseph (1985): 'Hybrid Buildings', Pamphlet Architecture 11.

Gruen, Victor (1973): Centers for the Urban Environment. Survival of the Cities (Van Nostrand Reinhold, Nueva York).

Holley, Michel (2012): Urbanisme vertical \& autres souvenirs (Somogy éditions d'art, París).

Jacobs, Jane (1961): The Death and Life of Great American Cities (Random House, New York).

Koolhaas, Rem (1978): Delirious New York (Oxford University Press, London)

Maki, Fumihiko (1964): Investigations in Collective Form (Washington University, Saint Louis),

Martí Arís, Carlos (1991): Las formas de residencia en la ciudad moderna (UPC, Barcelona).

Mozas, Javier (2008): 'Usos mezclados. Un recorrido histórico', a+t Revista independiente de arquitectura + tecnología, 32, 4-25.

Pérez Igualada, Javier (2005): Manzanas, bloques y casas. Formas construidas y formas del suelo en la ciudad contemporánea (Universidad Politécnica de Valencia, Valencia).

Pérez Igualada, Javier (2008): 'Si cambia la vivienda, cambia la ciudad. La vivienda pequeña y sus formas de agrupación en la Valencia de posguerra', en AA.VV., Renta limitada. Los grupos de viviendas baratas construidos en la Valencia de posguerra (1939-1964) (Universidad Politécnica de Valencia, Valencia) 40-48. 
Pérez Igualada, Javier (2014): 'Ecos del norte: la manzana híbrida en el Proyecto para la Avenida de Valencia al Mar de Fernando Moreno Barberá (1959-60)', ACE: Architecture, City and Environment $=$ Arquitectura, Ciudad y Entorno, 9, 29-52.

Terence Riley, ed (2002): The Changing of the Avant-Garde: Visionary Architectural Drawings from the Howard Gilman Collection (New York: The Museum of Modern Art) 122-24. 